\title{
Agroeconomic Production and Antioxidant Activity of the Hibiscus Cultivated Under Organic Practices and Plant Arrangements
}

\author{
Heldo D. V. Rosa Aran ${ }^{1}$, Néstor A. Heredia-Zárate ${ }^{1}$, Willian Vieira Gonçalves ${ }^{1}$, Silvia Cristina Heredia-Vieira ${ }^{2}$, \\ Maiane J. Pereira ${ }^{3}$, Jackeline S. Soares ${ }^{3}$, Kaliana G. de Freitas ${ }^{1}$, Cláudia Andrea de L. Cardoso ${ }^{3}$ \\ \& Maria do Carmo Vieira ${ }^{1}$ \\ ${ }^{1}$ Federal University of Grande Dourados, MS, Brazil \\ ${ }^{2}$ Anhanguera-Uniderp University, Campo Grande, Brazil \\ ${ }^{3}$ Estadual University of Mato Grosso do Sul, Dourados, MS, Brazil \\ Correspondence: Maria do Carmo Vieira, Federal University of Grande Dourados, MS, Brazil. Tel: 67-9219-8937. \\ E-mail: mariavieira@ufgd.edu.br
}

Received: October 24, 2021

doi:10.5539/jas.v14n1p60
Online Published: December 15, 2021

URL: https://doi.org/10.5539/jas.v14n1p60

The research is financed by FUNDECT, CAPES and CNPq.

\begin{abstract}
In order to obtain better productivity and a good level of secondary metabolites for cultivating plants with organic residues, it is necessary to define the method of application and the best combination considering plant density. Our objective was to study the influence of the plant arrangement and methods of application of poultry manure in the soil over agroeconomic performance and the antioxidant activity of the hibiscus. Treatments in the field consisted of two plant arrangements (single or double rows, both with 0.50 meters between plants) and four methods of application of poultry manure to the soil [incorporating $\left(10 \mathrm{th}^{-1}\right)$, mulching $\left(10 \mathrm{tha}^{-1}\right)$, mulching $(5 \mathrm{t}$ $\left.\mathrm{ha}^{-1}\right)+$ incorporating $\left(5 \mathrm{t} \mathrm{ha}^{-1}\right)$ and a control—no poultry manure] and, in the laboratory, antioxidant activity in relation to the treatments in the field and preparation methods (maceration or infusion). Treatments were arranged in randomized blocks of $2 \times 4$ with four replicates. The greatest production of dried calyx $\left(0.68 \mathrm{tha}^{-1}\right)$ and of capsules $\left(1.32 \mathrm{t} \mathrm{ha}^{-1}\right)$, the greatest number of fruits $\left(2.10\right.$ million $\left.\mathrm{ha}^{-1}\right)$ and the greatest net income (R \$ 36,115.42) resulted of plants cultivated in single rows with the poultry manure covering the crops. The antioxidant activity of the hibiscus calyces showed no variation in relation with field treatments or with the method of preparation. Cultivation in single rows covered with poultry manure is adequate for the hibiscus plant.
\end{abstract}

Keywords: Hibiscus sabdariffa L., roselle, aqueous extract, plant density, organic residue

\section{Introduction}

The hibiscus (Hibiscus sabdariffa L., Malvaceae) is among the species that can adapt to the organic practices, as this species originated in Africa, where the environment is tropical, with highly weathered soils, and, therefore, adapts well to tropical and subtropical climates, being cultivated worldwide. The entire plant is used for food, medicinal and ornamental purposes. The calyces are used for human food, especially in the form of teas, juices, jam and refreshments (Amaro et al., 2013; Nyam et al., 2014).

One of the compelling aspects of the roselle is the antioxidant effect of its calyces, which, in the past years, has raised great interest, both in the form of studies and in the use of the substances with this effect, as they reduce free radicals and other oxidizing agents in the body. These molecules are unstable and highly reactive, precursors of many degenerative diseases associated with aging, such as cancer, cardiovascular diseases, cataracts, weakening of the immune system and brain disorders (Seeram \& Nair, 2002; Lin et al., 2007). Pharmacological studies with ethanolic extracts from roselle leaves and calyces have shown the therapeutic effects such as antioxidant and antibacterial. In vitro and in vivo studies demonstrated antimicrobial, antiparasitic and anti-cancer effects (Ramos et al., 2011a; Maciel et al., 2012; Hassan et al., 2016).

Due to the great potential in its use and ability to adapt, the hibiscus can be considered promising cultivation for producers; therefore, it is important to have well-established cultivation practices for its production, targeting 
greater productivity. It is known that both biomass production and the level of secondary metabolites of plants can be influenced by cultivation treatments, among them being the organic and conventional production practices, as well as plant density and arrangement.

The use of organic residues appeared to be promising when Dahmardeh (2012) observed that the use of chicken manure $\left(20 \mathrm{tha}^{-1}\right)$, covering the soil, resulted in a difference of $0.72 \mathrm{t} \mathrm{ha}^{-1}$ between the highest $\left(1.61 \mathrm{tha}^{-1}\right)$ and lowest $\left(0.89 \mathrm{t} \mathrm{ha}^{-1}\right)$ productivity of fresh hibiscus calyces. Such results demonstrate that this residue contains nutrients and organic matter, and when added to the soil through covering/mulch, it benefits improvements in the physical, chemical and biological characteristics of the soil (Dalólio et al., 2017).

Planting density and the arrangement of plants in the rows, whether single or double, interfere with the productivity. For the hibiscus, Ramos et al. (2011b) observed that denser spacing resulted in a smaller production of fruit per plant, but in higher productivity per area. The authors observed that the highest production values of fresh and dry mass of leaves, stems, and fruit (33.96 tha $\mathrm{th}^{-1}$ of fresh mass and $4.04 \mathrm{t} \mathrm{ha}^{-1}$ of the dry mass of fruit) of the hibiscus plant were obtained in soil with poultry manure.

Based on the above-mentioned remarks, the objective of this study was to evaluate the influence of the plant arrangement and methods of adding poultry manure to the soil on agroeconomic performance and the antioxidant activity of the hibiscus.

\section{Method}

\subsection{General Aspects}

The experiment was conducted in the field, at the Garden of Medicinal Plants (GMP) of the Federal University of Grand Dourados $\left(22^{\circ} 11^{\prime} 44^{\prime \prime} \mathrm{S}\right.$ and $54^{\circ} 56^{\prime} 08^{\prime \prime} \mathrm{W}$, in $\left.452 \mathrm{~m}\right)$, in Dourados, MS, Brazil, between July 2015 and June 2016. The climate in the region, following the Köppen-Geiger climate classification is the Am type (Alvares et al., 2014) and the average maximum and minimum temperature, and total precipitation throughout the experiment period were $29.4{ }^{\circ} \mathrm{C} ; 18.3{ }^{\circ} \mathrm{C}$ and $1,988.8 \mathrm{~mm}$, respectively. The conduction of the experiment was carried out according to the precepts of organic farming for medicinal plants. This area has been under biological management for more than 20 years. The soil in the experiment area, originally within Cerrado vegetation (open pasture with patches of stunted vegetation), was flat and classified as dystrophic Red Oxisols, with an extremely clay-like texture, of which the chemical characteristics before the implementation of the experiment were: $\mathrm{Ca}=3.51 \mathrm{cmol}_{\mathrm{c}} \mathrm{dm}^{-3} ; \mathrm{Mg}=1.73 \mathrm{cmol}_{\mathrm{c}} \mathrm{dm}^{-3} ; \mathrm{Al}=0.10 \mathrm{cmol}_{\mathrm{c}} \mathrm{dm}^{-3}$ (KCI Extraction); $\mathrm{K}=0.54$ $\mathrm{cmol}_{\mathrm{c}} \mathrm{dm}^{-3} ; \mathrm{P}=14.33 \mathrm{mg} \mathrm{dm}{ }^{-3} ; \mathrm{Fe}=40.10 \mathrm{mg} \mathrm{dm}{ }^{-3} ; \mathrm{Mn}=67.30 \mathrm{mg} \mathrm{dm}^{-3} ; \mathrm{Cu}=10.40 \mathrm{mg} \mathrm{dm}{ }^{-3} ; \mathrm{Zn}=1.80 \mathrm{mg}$ $\mathrm{dm}^{-3}$ (Extracted with Mehlich-1); $\mathrm{B}=0.19 \mathrm{mg} \mathrm{dm}\left(\mathrm{HCl}\right.$ Extraction $0.05 \mathrm{~N}$ ); $\mathrm{MO}=27.31 \mathrm{~g} \mathrm{dm}^{-3}$ (Sodium dichromate extraction); $\mathrm{S}=5.78 \mathrm{cmol}_{\mathrm{c}} \mathrm{dm}^{-3} ; \mathrm{H}+\mathrm{Al}=5.76 \mathrm{cmol}_{\mathrm{c}} \mathrm{dm}^{-3} ; \mathrm{pH} \mathrm{CaCl}=4.80$ and $\mathrm{pH}$ water: $5.40 ; \mathrm{V} \%$ $=56.41$.

\subsection{Growth and Development in the Field}

Plant propagation of the hibiscus was carried out through indirect seeding, using seeds collected from plants cultivated at the GMP of UFGD (Access Registration No. A9CDAAE-Genetic Heritage Management Council-Ministry of the Environment-CGEN-MMA, from 15/10/2018). A sample is deposited at the DDMS Herbarium, of the Federal University of Grande Dourados, under number 1710. The seedlings were produced in polystyrene trays 128 cells, with Topstrato ${ }^{\circledR}$ substrate, kept in a protected environment with $50 \%$ sombrite ${ }^{\circledR}$, with daily irrigation.

The studied factors were planted arrangements (single rows or double rows) and methods for adding the poultry manure [incorporating $\left(10 \mathrm{t} \mathrm{ha}^{-1}\right)$, mulching $\left(10 \mathrm{t} \mathrm{ha}^{-1}\right)$, incorporating $\left(5 \mathrm{tha}^{-1}\right)+$ mulching $\left(5 \mathrm{t} \mathrm{ha}^{-1}\right)$ and a control — no poultry manure]. Spacing between plants was $0.50 \mathrm{~m}$, between single rows $0.5 \mathrm{~m}$ and between double rows $1.00 \mathrm{~m}$, with populations of 13.200 and 26.400 plants ha $^{-1}$ for single and double rows, respectively. Treatments were arranged in randomized blocks of $2 \times 4$ with four replicates. The total area of the plots was 4.5 $\mathrm{m}^{2}\left(1.5 \mathrm{~m}\right.$ width $-3.0 \mathrm{~m}$ length) and a useful area of $3.0 \mathrm{~m}^{2}$ (1.0 m width and $3.0 \mathrm{~m}$ length).

The analysis of the chemical composition of the poultry manure used was carried out according to Silva (2009) and the results were: $\mathrm{N}=23.90 \mathrm{~g} \mathrm{~kg}^{-1} ; \mathrm{P}=15.36 \mathrm{~g} \mathrm{~kg}^{-1} ; \mathrm{K}=20.00 \mathrm{~g} \mathrm{~kg}^{-1} ; \mathrm{Ca}=19.15 \mathrm{~g} \mathrm{~kg}^{-1} ; \mathrm{Mg}=6.95 \mathrm{~g} \mathrm{~kg}^{-1} ; \mathrm{S}$ $=18.65 \mathrm{~g} \mathrm{~kg}^{-1} ; \mathrm{C}=260.00 \mathrm{~g} \mathrm{~kg}^{-1} ; \mathrm{MO}=447.00 \mathrm{~g} \mathrm{~kg}^{-1} ; \mathrm{Cu}=130.00 \mathrm{mg} \mathrm{kg}{ }^{-1} ; \mathrm{Zn}=136.00 \mathrm{mg} \mathrm{kg}^{-1} ; \mathrm{Fe}=950.00$ $\mathrm{mg} \mathrm{kg}{ }^{-1} ; \mathrm{Mn}=840.00 \mathrm{mg} \mathrm{kg}^{-1} ; \mathrm{B}=4.50 \mathrm{mg} \mathrm{kg}^{-1} ;$ Humidity $11.03 \%$; $\mathrm{pH}$ water $=7.50$.

A week before the transplant, the soil was plowed and harrowed with a tractor, and the seedbeds were raised with a rotary seedbed lifter. The application of the poultry manure by incorporating it $\left(10 \mathrm{tha}^{-1}\right.$ or $\left.5 \mathrm{t} \mathrm{ha}^{-1}\right)$ was carried out one day before the transplant of the seeds, distributing it through broadcast seeding over each section of the seedbed, incorporating it with a tractor subsequently, at a depth of 0.0 to $0.20 \mathrm{~m}$; the application through 
mulching (10 tha has $\left.5 \mathrm{t} \mathrm{ha}^{-1}\right)$ was carried out through broadcast seeding over each corresponding section, immediately after the transplant of the seedlings. Lime was not used as a soil amendment during the crop cycle, nor any other fertilization technique. Transplanting to the field took place when the plant height was around 10 $\mathrm{cm}, 60$ days after sowing. Throughout the crop cycle, the field cultural practices consisted of irrigation sprinkling and manual hoeing in the rows and with hoes between rows. There was no presence of plant pathogens nor pest attacks towards the plants.

\subsection{Evaluated Characteristics}

Throughout the cultivation cycle, the heights of the plants were measured, every 30 days, from the $30^{\text {th }}$ day after the transplant (DAT), until the $240^{\text {th }}$ DAT. Six harvests of fruit from plants from each plot were made every 15 days, beginning on the $180^{\text {th }}$ DAT until $240^{\text {th }}$ DAT, manually, with pruning shears, cutting the stem $0.5 \mathrm{~cm}$ below the base of the sepal; a size larger than $3.5 \mathrm{~cm}$ was an indication that the fruit was ready to be harvested. The fruits were counted in order to obtain the total number and the fresh and dry mass of the whole fruit, calyces and the capsules were evaluated. To evaluate the fresh mass, the entire fruit was weighed, then the capsules were separated from the calyces and the fruit was weighed again, using a numerical scale.

In order to obtain the dry mass, the calyces and capsules were put into paper bags and, after, put in an oven with forced air circulation at a temperature of $60 \pm 5{ }^{\circ} \mathrm{C}$ until a constant weight was achieved, and then they were weighed. The production was added in order to obtain the total production of fresh and dry mass. At 270 DAT, the plants were cut at soil level and weighed in order to determine the fresh and the dry mass of the aerial part.

The data averages of plant height were submitted for analysis of variables in portions subdivided into time; arrangement and application method with a $2 \times 4$ factorial design in each portion and the time (evaluation during the plant cycle) in the sub-portion; when the $\mathrm{F}$ test showed meaningfulness at $5 \%$ of probability, regression equations were adjusted or compared through Tukey's range test. The obtained data were submitted for analysis of variables and, when the $\mathrm{F}$ test showed meaningfulness at $5 \%$ of probability, they were compared through Tukey's range test. All analyses were performed using the statistical software SAEG 9.1 (SAEG, 2007).

\subsection{Economic Worth}

The production costs for cultivation of 1.0 ha of hibiscus plants were calculated using the table presented by Heid et al. (2015) as a base, where varying, fixed and other costs are considered. All costs were based on the Commerce of Dourados-MS (personal communication, 2016), at the time of the development of the experimental paper, except for the seeds and interest. The varying costs were formulated: (a) supplies, where polystyrene trays 128 cells ( $\mathrm{R} \$ 12.00$ unit $^{-1}$ ); the seeds, considering the populations, the probable losses in the field and the germination rate of the seeds (R\$ 98.001000 seeds $^{-1}$ ) (Sanyki Sementes e Mudas, 2016); commercial substrate calculated according to the weight of the volume used to fill the trays ( $R \$ 33.00 \mathrm{bag}^{-1} \mathrm{of}_{25}$ $\mathrm{kg}$ ) and the semi-decomposed poultry manure ( $\left.\mathrm{R} \$ 90.00 \mathrm{t}^{-1}\right)$; (b) Labor, for sowing, transplant, distribution of poultry manure in the soil, irrigation, weeding and harvesting, considering men/day multiplied by the value of temporary labor (R\$ $45.00 \mathrm{day}^{-1}$ ); (c) Machinery, such as the irrigation pump and tractor for the preparation of the soil and the incorporation of the poultry manure, according to the registration of hours spent in the execution of each operation and multiplied by the cost amount of each piece of machinery.

The fixed costs were made up of: (a) Remuneration for use of the land, which corresponded to the time of use multiplied by the amount of monthly rent $\left(\mathrm{R} \$ 150.00 \mathrm{ha}^{-1}\right)$; (b) Improvements, corresponding to probable repairs of fences and buildings used through the time of cultivation and multiplied by $30 \%$ of the amount of monthly rent. Other costs were made up of: (a) Unforeseen events, corresponding to $10 \%$ of the sum of variable costs plus fixed costs, for use in different repairs of utensils and machinery, complementary labor, and others; (b) Administration, corresponding to $5 \%$ of the sum of variable costs plus fixed costs for payment of technical and administrative personnel; (c) Interest referring to the FCO (Constitutional Fund to Finance the Central-West) for the small producer, considering a monthly interest rate of $0.46 \%$ (Banco do Brasil, 2018), multiplied by the total cost of production throughout the time of use in the area. The estimates for gross profitability were determined by multiplying the average productivity rate for the dry mass of the hibiscus calyces for the price of R $\$ 72.00$ $\mathrm{kg}^{-1}$, which is the average amount paid to the producer. The net income was calculated by subtracting the production costs per cultivated hectare from the gross costs.

\subsection{Antioxidant Activity}

The dried calyces from each type of treatment were evaluated by infusion and maceration. To the infusion, for each $1.25 \mathrm{~g}$ of the dried calyces, $50 \mathrm{~mL}$ of distilled water $\left(80^{\circ} \mathrm{C}\right)$ was used, resulting in the concentration of 25 $\mathrm{mg} \mathrm{mL} \mathrm{m}^{-1}$. After a 15 -minute rest, the resulting liquid was filtered. To the maceration, for each $1.25 \mathrm{~g}$ of the dried 
calyces, $50 \mathrm{~mL}$ of distilled water at room temperature were added, resulting in the concentration of $25 \mathrm{mg} \mathrm{mL}^{-1}$. This was left to rest for $12 \mathrm{~h}$, in a refrigerator $\left(4 \pm 2{ }^{\circ} \mathrm{C}\right)$ and, after this period, the resulting liquid was filtered. All the procedure was carried out in triplicate. Then, $2 \mu \mathrm{l}$ for the aqueous extracts (infusion and maceration) from each type of treatment were placed in $5 \mathrm{~mL}$ pipettes of distilled water resulting in the concentration of $10 \mu \mathrm{g}$ $\mathrm{mL}^{-1}$.

To evaluate the antioxidant activities of the aqueous extracts, $2.5 \mathrm{~mL}$ to the solutions $\left(10 \mu \mathrm{g} \mathrm{mL}^{-1}\right) \mathrm{were}^{-1}$ added to $1.0 \mathrm{~mL}$ of a DPPH radical (2,2-diphenyl-1-picrylhydrazyl) methanolic solution $\left(0.03 \mathrm{mmol} \mathrm{mL} \mathrm{mL}^{-1}\right)$ and, after having rested for 30 minutes at room temperature and protected from the light, the absorbance values were measured at $517 \mathrm{~nm}$ using a UV-Vis spectrophotometer (BioTek model Epoch). A solution containing $2.5 \mathrm{~mL}$ of distilled water and $1.0 \mathrm{~mL}$ of a DPPH solution was used as negative control, having been submitted to the same procedure as the other samples (Sobota et al., 2016).

The results were expressed according to the percentage of inhibition, and this was calculated using the following equation: $\Delta 0 \%=100 \times(\mathrm{A} 0-\mathrm{A}) / \mathrm{A} 0$, where $\Delta 0 \%$ is the percentage of sequestration of the $\mathrm{DPPH}, \mathrm{A} 0$ is the absorbance of the blank, and $\mathrm{A}$ is the absorbance of the sample after a reaction time of 30 minutes.

The data averages were submitted to analysis of variables, and when the F test showed meaningfulness at 5\% of probability, they were compared through Tukey's range test. All analyses were performed using the statistical software SAEG 9.1 (SAEG, 2007).

\section{Results and Discussion}

\subsection{Growth and Development in the Field}

The height of the hibiscus plants was influenced by the interaction of plant arrangement in the seedbed with the evaluation periods, but no by the poultry manure. The growth was linear throughout the cultivation cycle, the maximum observed height having been $150.41 \mathrm{~cm}$ in the plants cultivated in double rows $(\hat{\mathrm{y}}=-24.38+0.7283 \mathrm{x}$; $\left.\mathrm{R}^{2}=0.87\right)$, with an increase of $14.54 \mathrm{~cm}$ in relation to the smaller maximum height $(135.87 \mathrm{~cm})$ from cultivation in single rows $\left(\hat{y}=-22.05+0.6599 x ; R^{2}=0.85\right)$, both at 240 DAT. The fact that the greatest height appeared in cultivation in double rows indicates that with the increase of plant density in the seedbed, the intraspecific competition for light was increased, resulting in the stimulation of apical dominance, resulting in higher plants, but with a smaller mass of leaves and branches (Taiz et al., 2017). These results differ from those reported by Ramos et al. (2011b), where they cultivated the hibiscus with differentiated spacing between plants, with or without the use of poultry manure, having observed linear growth in the plants due to the cultivation cycle, with a mean height of $261.88 \mathrm{~cm}$ on the $200^{\text {th }}$ DAT.

\subsection{Production of Fruit}

The total number of fruit, the fresh mass of the entire fruit, the fresh and dry masses of calyces and the fresh and dry mass of the capsules were influenced by the interaction between planting arrangement and the methods of adding poultry manure to the soil, the highest production having been observed with the addition of poultry manure through mulching and under the single row arrangement (Tables 1 and 2). 
Table 1. The fresh mass of the entire fruit, calyces and capsules of the hibiscus plant, cultivated in single and double rows in the seedbed and using four methods of addition of the poultry manure to the soil

\begin{tabular}{|c|c|c|c|c|c|c|}
\hline \multirow{4}{*}{ Studied factors } & \multicolumn{6}{|c|}{ Fresh mass $\left(\mathrm{t} \mathrm{ha}^{-1}\right)$} \\
\hline & \multicolumn{2}{|c|}{ Fruit } & \multicolumn{2}{|c|}{ Calyces } & \multicolumn{2}{|c|}{ Capsules } \\
\hline & \multicolumn{6}{|c|}{ Planting arrangement } \\
\hline & Single & Double & Single & Double & Single & Double \\
\hline \multicolumn{7}{|c|}{ Methods of adding poultry manure } \\
\hline Control & $10.75 \mathrm{bA}$ & $10.17 \mathrm{abA}$ & $5.75 \mathrm{Aa}$ & $5.52 \mathrm{aA}$ & $4.97 \mathrm{bA}$ & $4.64 \mathrm{aA}$ \\
\hline Incorporated (I) & $13.08 \mathrm{abA}$ & $8.87 \mathrm{bB}$ & $6.64 \mathrm{Aa}$ & $4.39 \mathrm{bB}$ & $6.41 \mathrm{aA}$ & $4.83 \mathrm{aB}$ \\
\hline Mulching (M) & $13.52 \mathrm{aA}$ & $10.57 \mathrm{abA}$ & $7.04 \mathrm{Aa}$ & $5.53 \mathrm{abB}$ & $6.32 \mathrm{abA}$ & $4.83 \mathrm{aB}$ \\
\hline $\mathrm{M}+\mathrm{I}$ & $10.64 \mathrm{bA}$ & $11.21 \mathrm{aA}$ & $5.55 \mathrm{Aa}$ & $5.84 \mathrm{abA}$ & $4.93 \mathrm{bA}$ & $4.67 \mathrm{aA}$ \\
\hline $\mathrm{CV}-\%$ & \multicolumn{2}{|c|}{26.46} & \multicolumn{2}{|c|}{28.25} & \multicolumn{2}{|c|}{28.80} \\
\hline
\end{tabular}

Note. The spacing between single rows was $1.50 \mathrm{~m}$, between double rows was $1.00 \mathrm{~m}$ and inside double rows was $0.50 \mathrm{~m}$. I (Incorporated): The poultry manure was incorporated into the soil to a depth of $0-20 \mathrm{~cm}$ one day before transplantation; M (Mulching): Soon after transplantation, poultry manure was applied on the soil surface of plots. Averages followed by distinct uppercase letters in the lines and lowercase letters in the columns differ from each other through the T test and Tukey's Test, respectively, at 5\% of probability. CV-\%: Coefficient of Variation.

Table 2. Dry mass of the calyces and capsules and number of fruits of the hibiscus plants cultivated in single and double rows in the seedbed and using four methods of addition of the poultry manure to the soil

\begin{tabular}{|c|c|c|c|c|c|c|}
\hline \multirow{4}{*}{ Studied factors } & \multicolumn{4}{|c|}{ Dry mass $\left(\mathrm{t} \mathrm{ha}^{-1}\right)$} & \multirow{2}{*}{\multicolumn{2}{|c|}{$\begin{array}{l}\text { Number of fruits } \\
\left(\text { Millions ha' }{ }^{-1}\right)\end{array}$}} \\
\hline & \multicolumn{2}{|c|}{ Calyces } & \multicolumn{2}{|c|}{ Capsules } & & \\
\hline & \multicolumn{6}{|c|}{ Planting arrangement } \\
\hline & Single & Double & Single & Double & Single & Double \\
\hline \multicolumn{7}{|c|}{ Methods of adding poultry manure } \\
\hline Control & $0.59 \mathrm{aA}$ & $0.65 \mathrm{aA}$ & $1.13 \mathrm{aA}$ & $1.23 \mathrm{Aa}$ & $1.63 \mathrm{bB}$ & $1.85 \mathrm{aA}$ \\
\hline Incorporated (I) & $0.62 \mathrm{aA}$ & $0.39 \mathrm{bB}$ & $1.31 \mathrm{aA}$ & $0.86 \mathrm{bB}$ & $1.93 \mathrm{abA}$ & $1.29 \mathrm{aB}$ \\
\hline Mulching (M) & $0.68 \mathrm{aA}$ & $0.52 \mathrm{abA}$ & $1.32 \mathrm{aA}$ & $1.05 \mathrm{abA}$ & $2.10 \mathrm{aA}$ & $1.47 \mathrm{aB}$ \\
\hline $\mathrm{M}+\mathrm{I}$ & $0.51 \mathrm{aA}$ & $0.55 \mathrm{abA}$ & $1.06 \mathrm{aA}$ & $1.08 \mathrm{abA}$ & $1.64 \mathrm{bA}$ & $1.77 \mathrm{aA}$ \\
\hline $\mathrm{CV}-\%$ & \multicolumn{2}{|c|}{25.70} & \multicolumn{2}{|c|}{23.15} & \multicolumn{2}{|c|}{23.79} \\
\hline
\end{tabular}

Note. The spacing between single rows was $1.50 \mathrm{~m}$, between double rows was $1.00 \mathrm{~m}$ and inside double rows was $0.50 \mathrm{~m}$. I (Incorporated): The poultry manure was incorporated into the soil to a depth of $0-20 \mathrm{~cm}$ one day before transplantation; M (Mulching): Soon after transplantation, poultry manure was applied on the soil surface of plots. Averages followed by distinct uppercase letters in the lines and lowercase letters in the columns differ from each other through the T test and Tukey's Test, respectively, at 5\% of probability. CV-\%: Coefficient of Variation.

Regarding the effects of the poultry manure through mulching, in the higher fruit production, it resulted in an improvement in the quality of the soil, as it favored the retention of humidity and the infiltration of water, by avoiding subsurface drainage; it improved the physical properties by increasing the stability of soil aggregates and, consequently, ventilation; it contributed to maintain soil fertility and temperature; it triggered microbiological processes, besides aiding in the control of spontaneous plants (Mangieri \& Tavares Filho, 2015; Dalólio et al., 2017). Ramos (2011b) also observed that the number of hibiscus fruits increased (27.71\%) by the addition of poultry manure to the soil, in relation to treatment without adding poultry manure, thus confirming that the use of poultry manure as organic residue can contribute to increment the productivity of the hibiscus plants, as it helps maintain lower temperatures in relation to the external environment, which will normally improve the water/thermal balance and the photosynthetic capacity of the plant. Besides this, the poultry manure may also have contributed to the addition of nutrients to the soil, such as $\mathrm{P}$ and $\mathrm{K}$, since organic fertilizers are characterized by high levels of organic matter, by the total levels of nutrients, especially N, P and K, by water content and an adequate $\mathrm{C}: \mathrm{N}$ ratio (Raij, 2011). 
The yields of the calyces obtained in this study resembled those obtained by Castro et al. (2004), who evaluated the months of implementation of organic production of the hibiscus (October, November, December and January), having found a mean production of dry calyces of $1.45 \mathrm{t} \mathrm{ha}^{-1}$. On the other hand, the production was lower than that obtained by Ramos et al. (2012), who studied methods of adding poultry manure to the soil and obtained the highest production of fresh mass $\left(10.8 \mathrm{t} \mathrm{ha}^{-1}\right)$ and dry mass $\left(1.2 \mathrm{th}^{-1}\right)$ and a greater number (3.980.602) of hibiscus calyces with the use of the poultry manure $\left(10 \mathrm{t} \mathrm{ha}^{-1}\right)$ covering the crops in the agricultural year 2009/2010. The different yields achieved are likely due to climatic conditions e and cultivation treatment, since variations in production between years are expected in upland conditions due to rainfall variability (Blaise, 2006), soil quality and temperature. Additionally, the highest yields achieved by Ramos et al. (2011b), in comparison with our work, are due to their evaluation methods, once the authors had measured the whole fruits (calyces and capsules).

The higher fruit production in plants under the single row arrangement was due to less competition over water, light and nutrients, which favored a better use of water and better photosynthetic efficiency, using metabolic processes to obtain greater mass accumulation (Taiz et al., 2017). The fact that lower productivity was observed under cultivation in double rows indicates that this population pressure was enough to cause a decrease in the production capacity of the plant, due to the competition over growth factors such as light, nutrients and water, which resulted in a decrease in productivity. Conversely, Ramos et al. (2011b) did not observe an influence of the spacing studies $(30,35,40,45$ and $50 \mathrm{~cm})$ on the production of fresh and dry mass, nor on the number of hibiscus fruits.

\subsection{Production of the Aerial Parts of the Plants}

The production of fresh and dry mass of the aerial parts of the plants, including the stems and leaves, were influenced by the planting arrangement and by the methods of addition of poultry manure to the soil, in an isolated manner. Through double rows, the fresh and dry mass of the aerial part had increases of 7.05 and $1.64 \mathrm{t}$ $\mathrm{ha}^{-1}$, respectively, in relation to cultivation in single rows (Table 3). Increased production resulted in a greater number of plants per area under double rows, which compensated for the decreased individual production, due to greater competition between the plants.

Table 3. Fresh and dry mass of the aerial parts of the hibiscus, cultivated in single and double rows in the seedbed and using four methods of addition of the poultry manure to the soil

\begin{tabular}{lll}
\hline Studied factors & Fresh mass of the aerial part $\left(\mathrm{t} \mathrm{ha}^{-1}\right)$ & Dry mass of the aerial part $\left(\mathrm{t} \mathrm{ha} \mathrm{p}^{-1}\right)$ \\
\hline $\begin{array}{l}\text { Planting arrangement } \\
\text { Single }\end{array}$ & $16.82 \mathrm{~b}$ & $4.43 \mathrm{~b}$ \\
Double & $23.87 \mathrm{a}$ & $6.07 \mathrm{a}$ \\
\hline Methods of adding poultry manure & & \\
Control & $19.38 \mathrm{~b}$ & $4.67 \mathrm{~b}$ \\
Incorporated (I) & $20.34 \mathrm{ab}$ & $5.25 \mathrm{ab}$ \\
Mulching (M) & $22.74 \mathrm{a}$ & $5.56 \mathrm{a}$ \\
M + I & $19.52 \mathrm{~b}$ & $4.50 \mathrm{~b}$ \\
CV-\% & 22.14 & 23.47 \\
\hline
\end{tabular}

Note. The spacing between single rows was $1.50 \mathrm{~m}$, between double rows was $1.00 \mathrm{~m}$ and inside double rows was $0.50 \mathrm{~m}$. I (Incorporated): The poultry manure was incorporated into the soil to a depth of $0-20 \mathrm{~cm}$ one day before transplantation; M (Mulching): Soon after transplantation, poultry manure was applied on the soil surface of plots. Averages followed by distinct letter in the columns differ from each other through the $\mathrm{T}$ test for planting arrangement and Tukey's test for poultry manure, respectively, at 5\% of probability. CV- $\%$ : Coefficient of Variation.

The reason for this is that, according to Nascimento et al. (2007), the species in general presented compensation mechanisms for producing, due to the modifications in their populations in associations and in special arrangements. The results relating to greater production under a greater plant density are coherent with those obtained by Ramos et al. (2011b), who, upon studying the hibiscus within different spacing between plants (30, $35,40,45$ and $50 \mathrm{~cm})$, obtained a greater performance in fresh mass $\left(31.6 \mathrm{tha}^{-1}\right)$ and dry mass $\left(3.3 \mathrm{tha}^{-1}\right)$ of the aerial part in denser cultivation $(30 \mathrm{~cm})$, lower performance of fresh mass $\left(24.3 \mathrm{tha}^{-1}\right)$ and dry mass $\left(2.3 \mathrm{tha}^{-1}\right)$ 
in cultivation with lower density $(50 \mathrm{~cm})$. Lower production in this study in relation to the studies carried out by the authors may be due to differences in climate conditions.

Similarly the addition of poultry manure to the soil, the method through mulching rendered greater production of fresh and dry mass in the aerial part, with an increase of $3.36 \mathrm{t} \mathrm{ha}^{-1}$ and $0.89 \mathrm{t} \mathrm{ha}^{-1}$, respectively, in relation to the lower fresh mass $\left(19.38 \mathrm{t} \mathrm{ha}^{-1}\right)$ and dry mass $\left(4.50 \mathrm{t} \mathrm{ha}^{-1}\right)$ in the aerial part, without the use of poultry manure. These results suggest that the poultry manure in mulching may have helped maintain the humidity of the soil and resulted in maintaining lower temperatures in relation to the external environment (Mangieri \& Tavares Filho, 2015), which may have improved the water/thermal balance and photosynthetic capacity of the plant, resulting in greater productivity (Taiz et al., 2017). It is important to add that a robust aerial part is desirable, not only as it results in a greater production of fruit, but also because the new leaves and branches also have nutritional with values comparable or superior to conventional leafy vegetables (Botrel et al., 2020).

\subsection{Economic Value}

The estimated costs for the cultivation of 1.0 ha of hibiscus plants, considering the planting arrangement and methods of addition of poultry manure to the soil, have a variation of $\mathrm{R} \$ 8,206.68$ between the highest cost (R $\$ 19,986.18)$, of cultivation in double rows with the addition of poultry manure to the soil through mulching and incorporation, and the lowest cost (R $\$ 11,779.50)$, of cultivation in single rows without the addition of poultry manure (Table 4$)$.

Table 4. Productivity of dry roselle calyces, gross income, production costs and net income for hibiscus plants cultivated in single and double rows and using four methods of addition of the poultry manure to the soil

\begin{tabular}{lllll}
\hline & $\begin{array}{l}\text { Productivity of dry mass } \\
\text { of the calyces }\left(\mathrm{t} \mathrm{ha}^{-1}\right)\end{array}$ & $\begin{array}{l}\text { Gross income } \\
\left(\mathrm{R} \$ \mathrm{ha}^{-1}\right)\end{array}$ & $\begin{array}{l}\text { Production Costs } \\
\left(\mathrm{R} \$ \mathrm{ha}^{-1}\right)\end{array}$ & $\begin{array}{l}\text { Net income } \\
\left(\mathrm{R} \$ \mathrm{ha}^{-1}\right)\end{array}$ \\
\hline $\begin{array}{l}\text { Single row } \\
\text { Control }\end{array}$ & 0.59 & 42564.96 & 11779.50 & 30785.46 \\
Incorporated (I) & 0.62 & 44548.56 & 13270.53 & 31278.03 \\
Mulching (M) & 0.68 & 49242.24 & 13126.82 & 36115.42 \\
$\mathrm{M}+\mathrm{I}$ & 0.51 & 37000.08 & 13539.99 & 23460.09 \\
\hline Double row & & & & \\
Control & 0.65 & 46977.84 & 17633.08 & 29344.76 \\
Incorporated (I) & 0.39 & 28438.56 & 19666.72 & 8771.84 \\
Mulching (M) & 0.52 & 37637.28 & 19725.55 & 17911.73 \\
$\mathrm{I}+\mathrm{M}$ & 0.55 & 39532.32 & 19986.18 & 19546.14 \\
\hline
\end{tabular}

Note. The spacing between single rows was $1.50 \mathrm{~m}$, between double rows was $1.00 \mathrm{~m}$ and inside double rows was $0.50 \mathrm{~m}$. I (Incorporated): The poultry manure was incorporated into the soil to a depth of $0-20 \mathrm{~cm}$ one day before transplantation; M (Mulching): Soon after transplantation, poultry manure was applied on the soil surface of plots. ${ }^{1} \mathrm{R} \$ 72.00 \mathrm{~kg}^{-1}-60 \%$ of the average amount for commercialization in the Dourados-MS market, in 2016.

The highest variable cost was that of cultivation in double rows with the addition of poultry manure to the soil through mulching and incorporation, representing 77.03\% (R\$15,395.06) of the total production cost (R \$ 19,986.18) and the lowest variable cost in association with cultivation in single rows, without the addition of poultry manure, which represented $70.27 \%(\mathrm{R} \$ 8,277.58)$ of the total production cost ( $\$$ 11,779.50). These differences between variable costs are related especially to the varying amounts of supplies, labor and machinery used for the formation of seedlings and conduction of the experiment in the field. The higher costs with supplies, labor and machinery were related to cultivation in double rows with the addition of poultry manure through mulching and incorporation, representing, respectively, 36.70\% (R\$7,335.06), 33.02\% ( $\$$ 6,600.00) and 7\% $(\mathrm{R} \$ 1,400.00)$ of the total production cost $(\mathrm{R} \$ 19,986.18)$ and the lower costs were associated with cultivation in single rows without the addition of poultry manure to the soil, which represented $27.31 \%$ ( $\$$ \$ 3,217.00), 32.09\% $(\mathrm{R} \$ 3,780.00)$ and $10.87 \%(\mathrm{R} \$ 1,280.00)$ of the total production cost (R\$ 11,779.50). The fixed costs (R $\$ 1,792.00$ ) represented $8.97 \%$ of the total production cost for cultivation in double rows with the addition of poultry manure through mulching and incorporation, and $15.21 \%$ of the total production cost for cultivation in single rows without the addition of poultry manure to the soil. 
Considering the mean productivity of the dry mass of hibiscus calyces, of the production costs and of the estimation for gross and net income (Table 4), it was concluded that the cultivation of the hibiscus in single rows with the addition of poultry manure through mulching resulted in greater production of dry calyces of hibiscus fruits $\left(683.92 \mathrm{~kg} \mathrm{ha}^{-1}\right)$, greater gross income $(\mathrm{R} \$ 49,242.24)$ and greater net income ( $\$$ \$ 36,115.42). Lower productivity $\left(394.98 \mathrm{~kg} \mathrm{ha}^{-1}\right)$, gross income $(\mathrm{R} \$ 28,438.56)$ and net income $(\mathrm{R} \$ 8,771.84)$ were obtained through cultivation in double rows with the addition of poultry manure incorporated into the soil. Observing the results, it can be concluded that the producer must be careful when choosing cultivation techniques, as relatively high productivity can be obtained, but, as production costs can be high, this can decrease profitability. The results also show that the cultivation of hibiscus plants can be considered a source that generates jobs in the agricultural sector, due to the elevated needs related to labor in cultivation treatment.

\subsection{Antioxidant Activity}

The results obtained showed that the hibiscus calyces have an antioxidant potential (Figure 1), as was shown by Mohd-Esa et al. (2010), who evaluated the antioxidant activity of different hibiscus organs and verified that the stems had the second highest activity, which was lower only in comparison with the seeds, showing the power of the stems in fighting free radicals. The plant has, in its chemical composition, anthocyanins, which are a subgroup of flavonoids that are highly present in their calyces and, this chemical class, is described in the literature, for being capable of fighting free radicals and, as a consequence, preventing or slowing down numerous types of diseases (Mohd-Esa et al., 2010; Abotaleb et al., 2019). When the antioxidant activity of the hibiscus calyces was evaluated in relation to the plant arrangement and use of poultry manure in the soil, there was no variation related to these cultivation treatments (Figure 1), regardless of the form of preparation of the extract. On the other hands, different results were obtained by Ramos et al. (2011a), who studied spacing between plants and the addition of poultry manure to the soil for hibiscus production, they found that the addition of poultry manure increased the potential results in both aqueous extracts (infusion) and ethanolic extracts.

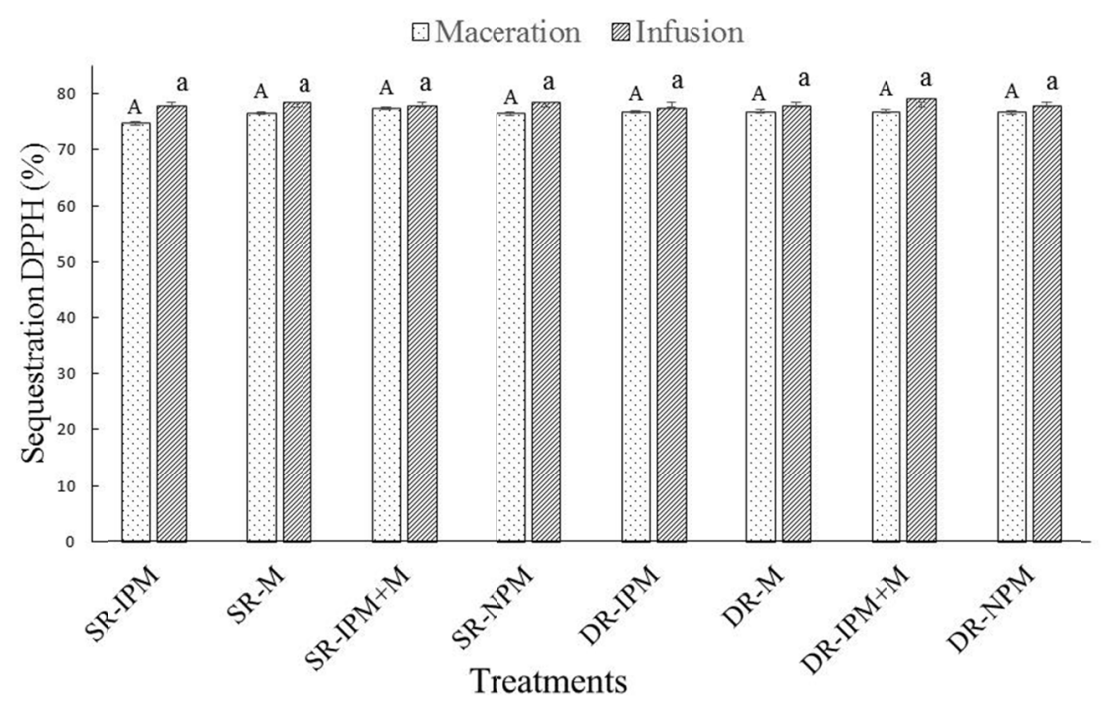

Figure 1. Sequestration of the DPPH observed in relation to planting arrangements and use of the poultry manure (Treatments) in cultivation and in relation to the preparation methods, maceration or infusion

Note. $\mathrm{T} 1=$ single row $(\mathrm{SR})$, incorporated poultry manure (IPM); T2 = SR, mulching (M); T3 = SR, incorporated + mulching; $\mathrm{T} 4=\mathrm{SR}$, no poultry manure $(\mathrm{NPM}) ; \mathrm{T} 5=$ double row $-\mathrm{DR}$, incorporated, $\mathrm{T} 6=\mathrm{DR}$, mulching; $\mathrm{T} 7=$ $\mathrm{DR}$, incorporated + mulching; $\mathrm{T} 8=\mathrm{DR}$, no poultry manure. Values expressed in mean \pm standard error of the mean. $\mathrm{n}=3$. Averages followed by same letters on the bars (capitals for maceration and lowercase for infusion) do not differ from each other through the Tukey's test for treatments, at $5 \%$ of probability. Coefficient of Variation $(\mathrm{CV}-\%$ : $)=4.9 \%$.

The extraction methods used (infusion and maceration) were evaluated for observations that these are the methods by which the population uses the hibiscus calyces. According to the results, it was observed that there was no difference in the antioxidant activity between the methods, observed media in $76.47 \%$ of sequestration of 
the DPPH to maceration and $78.03 \%$ to infusion. This shows that, when the use of the tea of this medicinal plant, is focused on its antioxidant potential, there is no difference between preparing it at the moment of ingestion, as long it is done by infusion, or leaving the calyces in contact with water overnight, for $12 \mathrm{~h}$, in the refrigerator (maceration). Previous studies, where different methods of extraction for the hibiscus were also compared, different results than those presented in this study were observed, as the extraction method had an influential role. Both Prenesti et al. (2007) and Sobota et al. (2016) has demonstrated that the decoction is the method that results in a product with greater antioxidant activity; however, the decoction was not assessed in this study.

\section{Conclusion}

Greater productivity of fresh and dry masses of hibiscus fruits, calyces and capsules was obtained in plants cultivated in single rows with the addition of poultry manure through mulching in the soil. These cultivation practices also provided the acquiring of higher net income. There was no variation in the antioxidant activity of the dry hibiscus calyces in relation to the treatments used in the cultivation of plants nor to the methods (maceration or infusion) used in the preparation of the extracts. Thanks to these results, the consumer will be free to use the calyces in tea and flavored water without loss of the antioxidant activity.

\section{References}

Abotaleb, M., Samuel, S. M., Varghese, E., Varghese, S., Kubatka, P., Liskova, A., \& Busselberg, D. (2019). Flavonoids in cancer and apoptosis. Cancers (Basel), 11(1), 28. https://doi.org/10.3390/cancers11010028

Alvares, C. A., Stape, J. L., Sentelhas, P. C., Gonçalves, J. L. M., \& Sparovek, G. (2014). Koppen's climate classification map for Brazil (2013). Metereologische Zeitschrift, 22, 711-728. https://doi.org/10.1127/ 0941-2948/2013/0507.

Amaro, H. T. R., David, A. M. S. S., Silva Neta, I. C., Alves, D. D., \& Silva, F. G. (2013). Physiological evaluation of seeds and growth of vinegar seedlings. Comunicata Scientiae, 4(1), 96-102. https://doi.org/ $10.14295 /$ cs.v4i1.167

Banco do Brasil. (2018). FCO Rural-Investimento Agropecuário. Retrieved November 11, 2018, from https://bityli.com/qOCWco

Blaise, D. (2006). Yield, boll distribution and fiber quality of hybrid cotton (Gossypium hirsutum L.) as influenced by organic and modern methods of cultivation. Journal of Agronomy and Crop Science, 192(4), 248-256. https://doi.org/10.1111/j.1439-037X.2006.00218.x

Botrel, N., Freitas, S., Fonseca, M. J. de O., Melo, R. A. de C., \& Madeira, N. (2020). Valor nutricional de hortaliças folhosas não convencionais cultivadas no Bioma Cerrado. Journal of Food Technology, 23, e2018174. https://doi.org/10.1590/1981-6723.17418

Castro, N. E. A., Pinto, J. E. B. P., Cardoso, M. G., Morais, A. R., Bertolucci, S. K. V., Silva, F. G., \& Delú Filho, N. (2004). Planting time for maximization of yield of vinegar plant calyx (Hibiscus sabdariffa L.). Ciência e Agrotecnologia, 28(3), 542-551. https://doi.org/10.1590/S1413-70542004000300009

Dahmardeh, M. (2012). Effect of mineral and organic fertilizers on growth and calyx yield of roselle (Hibiscus sabdariffa L.). African Journal of Biotechnology, 11(48), 10899-10902. https://doi.org/10.5897/AJB12.203

Dalólio, F. S., Silva, J. N., Oliveira, A. C. C., Tinôco, I. F. F., Barbosa, R. C., Resende, M. O., Albino, L. F. T., \& Coelho, S. T. (2017). Poultry litter as biomass energy: A review and future perspectives. Renewable and Sustainable Energy Reviews, 76(c), 941-949. https://doi.org/10.1016/j.rser.2017.03.104

Hassan, S. T. S., Berchová, K., \&·Udomová, M. (2016). Antimicrobial, antiparasitic and anticancer properties of Hibiscus sabdariffa (L.) and its phytochemicals: in vitro and in vivo studies. Česká a Slovenskáfarmacie, 65(1), 10-14.

Heid, D. M., Heredia Zárate, N. A., Vieira, M. C., Graciano, J. D., Figueiredo, P. G., Blans, N. B., \& Curioni, B. M. (2015). Agroeconomic productivity of mandioquinha-salsa in response to the addition of chicken manureto the soil. Ciências Agrárias, 36, 1835-1850. https://doi.org/10.5433/1679-0359.2015v36n3 Supl1p1835

Lin, T.-L., Lin, H.-H., Chen, C.-C., Lin, M.-C., Chou, M.-C., \& Wang, C.-J. (2007). Hibiscus sabdariffa extract reduces serum cholesterol in men and women. Nutrition Research, 27(3), 140-145. https://doi.org/10.1016/ j.nutres.2007.01.007 
Maciel, M. J., Paim, M. P., Carvalho, H. H. C., \& Wiest, J. M. (2012). Evaluation of the alcoholic extract of hibiscus (Hibiscus sabdariffa L.) as an antibacterial and antioxidant protection factor. Revista Instituto Adolfo Lutz, 71(3), 462-70. Retrieved September 11, 2021, from https://bityli.com/X6qmao

Mangieri, V. R. L., \& Tavares Filho, J. (2015). Solid waste disposal in the soil: Effects on the physical, chemical, and organic properties of soil. Semina: Ciencias Agrárias, 36(2), 747-764. https://doi.org/10.5433/ $1679-0359.2015 \mathrm{v} 36 \mathrm{n} 2 \mathrm{p} 747$

Mohd-Esa, N., Hern, F. S., \& Yee, C. L. (2010). Antioxidant activity in different parts of roselle (Hibiscus sabdariffa L.) extracts and potential exploitation of the seeds. Food Chemistry, 122, 1055-1060. https://doi.org/10.1016/j.foodchem.2010.03.074

Nascimento, E. X., Mota, J. H., Vieira, M. C., \& Heredia Zárate, N. A. (2007). Biomass production of Pfaffia glomerata (Spreng.) Pedersen and Plantago major L. in single and intercropping cultivation. Ciência e Agrotecnologia, 31(3), 724-730. https://doi.org/10.1590/S1413-70542007000300019

Nyam, K.-L., Leao, S.-Y., Tan, C.-P., \& Long, K. (2014). Functional properties of roselle (Hibiscus sabdariffa L.) seed and its application as bakery product. Journal of Food Science and Technology, 51(12), 3830-3837. https://doi.org/10.1007/s13197-012-0902-x

Prenesti, E., Berto, S., Daniele., P. G., \& Toso-Food, S. (2007). Antioxidant power quantification of decoction and cold infusions of Hibiscus sabdariffa flowers. Food Chemistry, 100(2), 433-438. https://doi.org/ 10.1016/j.foodchem.2005.09.063

Raij, B. V. (2011). Fertilidade do solo e manejo de nutrientes (p. 420). Piracicaba, International Plant Nutrition Institute.

Ramos, D. D., Vieira, M. C., Formagio, A. S. N., Cardoso, C. A. L., Ramos, D. D., \& Carnevali, T. O. (2011a). Antioxidant activity of Hibiscus sabdariffa L. as a function of spacing between plants and organic fertilization. Ciência Rural, 41(8), 1331-1336. https://doi.org/10.1590/S0103-84782011005000107

Ramos, D. D., Vieira, M. C., Heredia Zárate, N. A., Yamamoto, N. T., Carnevali, T. O., \& Souza, N. H. (2011b). Spacings between plants with chicken manure in roselle crop. Acta Scientiarum Agronomy, 33(4), 695-700. https://doi.org/10.4025/actasciagron.v33i4.6933

Ramos, D. D., Vieira, M. C., Heredia Zárate, N. A., Carnevali, T. O., Souza, N. H., \& Luciano, A. T. (2012). The biomass production and nutrient content of roselle leaves grown with poultry litter and organosuper ${ }^{\mathbb{B}}$. Acta Scientiarum, 34, 193-200. https://doi.org/10.4025/actasciagron.v34i2.12754

SAEG (Sistema para Análises Estatísticas). (2007). Versão 9.1: Fundação Arthur Bernardes. UFV, Viçosa, Brazil.

Sanyki Sementes e Mudas. (2016). Mercado livre: Hibiscus sabdariffa. Retrieved June 20, 2016, from https://lista.mercadolivre.com.br/_CustId_34052724

Seeram, N. P., \& Nair, M. G. (2002). Inhibition of lipid peroxidation and structure-activity-related studies of the dietary constituents anthocyanins, anthocyanidins, and catechins. Journal of Agricultural and Food Chemistry, 50(19), 5308-5312. https://doi.org/10.1021/jf025671q

Sobota, J. F., Pinho, M. G., \& Oliveira, V. B. (2016). Physical-chemical profile and antioxidant activity from the aqueous and alcoholic extract obtained by infusion and decoctionofcalyces of the species Hibiscus sabdariffa L. Revista Fitos, 10(1), 33-46. https://doi.org/10.5935/2446-4775.20160004

Silva, F. C. (2009). Manual de análises químicas de solos, plantas e fertilizantes (2nd ed., p. 627). Brasília, DF: Embrapa Informação Tecnológica.

Taiz, L., Zeiger, E., Moller, I. M., \& Murphy, A. (2017). Fisiologia e desenvolvimento vegetal (recurso eletrônico) (6th ed., p. 858). Porto Alegre: Artmed. Retrieved September 20, 2021, from https://bityli.com/ B5ZGXN

\section{Copyrights}

Copyright for this article is retained by the author(s), with first publication rights granted to the journal.

This is an open-access article distributed under the terms and conditions of the Creative Commons Attribution license (http://creativecommons.org/licenses/by/4.0/). 